\title{
The 'Fredo Factor:' How Deadbeats and Troublemakers Hurt Family Businesses
}

\author{
Kimberly Eddleston (Northeastern University)
}

KEYWORDS: Entrepreneurship, Management, Leadership, Family Business.

The Corleones of "Godfather" fame are an extreme example of a "family business." But like many family businesses, they have a family member who is a serious hindrance to their business, is less capable than nonfamily employees, and looks to exploit the family business for personal gain. We are referring to Fredo -the middle brother of the Corleone family who is known for his incompetence, bad business ideas, heavy drinking and betrayals. Unfortunately, Fredos are not only found in works of fiction. Our 2012 study revealed that approximately one-third of family businesses admit to having a family employee who is an impediment to the business and only has a job because he or she is 'family' (Kidwell, Kellermanns \& Eddleston, 2012).

We call these disruptive family members "Fredos," after the Corleone brother who just couldn't get it right, no matter how hard he tried. Because he was family, Fredo was involved in the family's business ventures, but he was constantly failing at even the simplest tasks he was given. The family even moved him to Las Vegas in hopes of minimizing his damage to the business. Ultimately his screw-ups and selfishness lead to serious problems for the Corleone's, which result in his own brother casting him out of the business and disowning him. If you watched Godfather II you know how it turns out for Fredo.

While Fredo's behavior from the Godfather movies was extreme, it is not uncommon for family businesses to have a family employee who consistently shows up late for work, fails to complete work properly and on time, misuses company resources and damages the work of colleagues. A "Fredo" can appear in a family business when the head of the business is more motivated to involve family members in the firm than to select them based on their skills and the needs of the business - in other words, when the head of the company is behaving more like a parent than a boss. Further, because parents have a hard time punishing bad behaviors, over time the Fredo's behavior tends to get worse. Many families will even reward their Fredo with promotions and compensation despite their incompetence and laziness in hopes that they will become motivated and change. For example, when an owner of a construction business realized that his sister had been stealing over $\$ 10,000$ per year as his bookkeeper, rather than terminate her he gave his sister a raise. He explained to his children that the raise was justified since his sister felt that she had been underpaid for the last few years. However, by rewarding his sister for such bad behavior, other family members were left dismayed and feeling unappreciated for their honesty and loyalty. Further, nonfamily employees felt a sense of injustice since they would have been fired for the same bad behavior.

Our team - which also included Roland E. Kidwell of Florida Atlantic University, John James Cater III of the University of Texas at Tyler and Franz W. Kellermanns of the University of North Carolina at Charlotte -- studied "The Fredo Effect" (and coined the term) to identify factors that increase their likelihood in a family business and to determine how they can be prevented.

\section{How Fredos Happen}

At the heart of the Fredo Effect are inconsistencies between how a healthy family works and how a healthy business works. In a family, resources such as love, guidance and money are often allocated according to equality and what each child needs, with the more fragile or uncertain child needing more support from time to time. Thus, the family is expected to care for one another, especially when one is in need. When this logic transfers to the business, however, it can be dangerous since it encourages the family to compensate for the weaknesses and failings of family members and to forgive indiscretions. In "The Godfather" novels, Vito Corleone realizes his son Fredo's shortcomings, but he insists that Fredo has a place in the family business. Initially, his brother Michael also forgives his mistakes and tries to find Fredo a job where he will do the least amount of harm. Similar to The Godfather movie, we have witnessed multiple family businesses that
Copyright @ The Authors. Entrepreneur \& Innovation Exchange is published at EIX.org. This is an open access article under the terms of the Creative Commons Attribution-NoDerivs License, which permits use and distribution in any medium, provided the original work is properly cited and no modifications or adaptations are made. View EIX.org Authorship Terms at https://eix.org/terms
FamilyBusiness 
continually move their Fredo to new positions in hopes that the change will isolate their poor performance from the rest of the business.

In contrast to the norms of the family, in a healthy business merit decides the allocation of resources like salaries, bonuses and other perks. When a child joins a family business expecting the same treatment he or she experiences in the family, where resources are allocated based on equality and need, trouble can result. Patriarchs that treat family employees as children encourage immaturity and dependence, and lead family employees to see them as responsible for their wellbeing. Moreover, well-meaning family patriarchs often feel they must reward their children equally in the business realm, without regard to their contributions. Their altruism ends up hurting them and costing the business. In one family business we know, a son was given a company car because he spent at least three days on the road each week meeting with customers throughout New England. On hearing the news, his three siblings, none of whom travel for work, demanded company cars. The siblings felt it was not 'fair' that he received a car and they did not. Situations like this, which are very common in family businesses, demonstrate how family members often expect resources and rewards to be allocated based on the family norm of equality rather than the business norm of merit.

Research also explains how adult children's relationship and bonds with parents spill into the working relationship, amplifying positive and negative interactions at work. A parent and child who share a close bond will likely work well together and the child's commitment to the parent will likely transfer to the business. In contrast, poor parent-child relationships are likely to intensify in the family business, making for difficult and tense interactions. As a result of these negative interactions, some children will either withdraw from the family business, thus minimizing their contributions, or lash out with selfish behaviors in an effort to gain compensation for their circumstances.

As Fredo demonstrates, these bad apples can disrupt both family relationships and the firm. Continuing to reward Fredos while ignoring their damaging behavior leads to more problems: the child's sense of entitlement increases, higher levels of relationship conflict in the family firm result, and more problems with productivity and teamwork emerge.
Now it's time to ask yourself: Do you have a Fredo in your family business?

Is there a family member in your business who:

- Could not find employment if they did not work for the family business?

- Consistently under-performs?

- Only has a job because he/she is family?

- Is less competent than most non-family employees?

If you answered "yes" to any of these questions, you likely have a family employee who is doing more harm than good for your business. You likely have multiple stories about how your Fredo has hurt your business as well as family relationships. But, you are not alone.

\section{Real-Life Fredos at Work}

While the Corleones are fictitious, we have seen many real-life examples of Fredos who wreak havoc on their family's business. In Chicago, fighting between brothers in the Rosen family's liquor empire led to the business being dissolved. Adelphia Communications suffered when family members used company funds as their personal piggy bank.

A real estate agency, owned by two brothers, repeatedly suffered at the hands of a Fredo, who was the son of the oldest brother. The oldest brother insisted that his son, Jake, work for the family business. After paying for his real estate license, Jake worked as a real estate agent, although he never gained any listings or sold a home without his father's help. After complaints from fellow real estate agents at the firm for his lack of effort and poor customer service, the father paid for Jake to earn his appraiser's license. This did not work either, since Jake would often miss appointments and make errors in his work. For a couple of years the father was able to help Jake with his appraiser work and hide his son's incompetence, but over time, Jake relied more and more on his father to do his work -- which became quite obvious to coworkers and especially Jake's uncle, who had brought in his two children Jimmy and Holly into the business. Things came to a head when Jimmy discovered that Jake was vacationing in Florida when he was scheduled to do a large appraisal job for the business. Their inability to find a replacement caused them to lose the job and an important account with a bank. However, while Jimmy and his father wanted Jake to be reprimanded, Jake's father refused and 
continued to make excuses for Jake. Jake's father also continued to insist that Jake make the same salary as Jimmy despite the fact that Jimmy worked almost twice the hours as Jake and rarely missed working a weekend.

Another example comes from a small high-end retail chain that had to deal with multiple Fredos who felt entitled to goods for their personal use. Two daughters would often "shop" at the stores, taking merchandise without paying or documenting what they took. One clerk was almost terminated because of missing merchandise after her shift and a daughter's reluctance to admit that she had taken the clothing. When a cousin of the daughters started working at one of the stores, things got even worse since she had access to the cash registers. The daughters and cousin started to take cash out of the registers to pay for their nights out. Eventually the small chain went bankrupt because the older generation never put an end to the girls' misbehavior.

Such dilemmas are not uncommon in family firms, which account for about $80 \%$ of businesses. Family members sometimes feel a sense of entitlement, deserving of rewards and privileges without earning it and an equal share of the business's riches, simply because they are part of the family. This undermines their relationships with the more hardworking family members at the firm, as well as other coworkers and customers. Research has shown that children with a strong sense of entitlement may be more likely to engage in theft because they see the business's riches as compensation for their poor and neglected childhood during the firm's early-year struggles. No wonder that those who study family businesses have found that $85 \%$ of them go from "shirtsleeves to shirtsleeves" by the third generation.

\section{How Can You Minimize the Damage from a Fredo?}

No family wants their business to end up like the Corleones'. So how can you deal with your own Fredo situation? First, while it's difficult to do, you must have a firewall between how you run your family and how you run your business. Resist the urge to include all family members in the trusted inner circle of your business; make it clear that both family members and outsiders must earn their way in. Also, create HR practices that encourage accountability, transparency and consequences for bad behaviors. Here are several other steps you can take before and after hiring a family member to make sure there are no weak links in your chain:

\section{Try Not to Hire a Fredo}

- Develop rules of entry for family members, such as minimum education level and years of experience, and stick to them. Further, by communicating rules of entry to the family, unfit family members are often dissuaded from applying for jobs that they are not qualified for (saving you the hassle of having to reject their job application).

- Set the same hiring standards for family members as you would for non-family employees.

- Make sure each family member is able to contribute to the business. In other words, don't create jobs for relatives just for the sake of giving them a job.

- Don't force family members into the firm if they don't want to be there. If family members dislike the industry or the job, it is difficult for them to be committed to the firm's mission and to devote $100 \%$.

- If you feel you must hire a family member with questionable abilities and/or drive, place him or her in a job where the rewards are based on commission, such as sales.

\section{Once You've Hired a Family Member, Watch for Fredo Behavior}

- Hold the person to the same standards to which you hold non-family employees, including the same human resources practices.

- Monitor the person to the same extent, too. This means developing job requirements to use in evaluating employees; family and non-family alike. Having clear job requirements tend to decrease the prevalence of Fredos since they know what tasks are expected of them and how their performance will be evaluated.

- Hold the person accountable for his or her actions, just as you would an employee who's not related to you.

- Do not allow family employees to have special privileges. This creates an us-against-them 
mentality with non-family employees, spurring feelings of injustice. It also encourages a sense of entitlement among family.

\section{How to Get Rid of a Fredo}

Don't worry, we don't mean it in the Corleone way. Here's how:

- Confront the Fredo, either one-on-one or via a trained third-party adviser. Sometimes Fredos do not realize the harm of their actions; this opens dialogue aimed to uncover causes of bad behavior and to develop possible solutions.

- Show that the bad behavior has consequences, like suspension or demotion. Make sure the punishment fits the crime and that the consequence does not reflect a preference for family over non-family employees.

- Find Fredo another job - one that better suits his/her interests and experience. Sometimes an otherwise "good" family member can seem like a Fredo because the person is ill-suited to the industry and business. Career counseling can also be helpful in this circumstance.

- Consider firing the Fredo or buying out his or her stock.

- Unfortunately, in reality, there are also situations when firing the Fredo is not practical since the person does not have career options and needs to provide for a family. Under these circumstances the best solution is finding Fredo a job in the business where he or she will do the least amount of harm, financially and emotionally.

While dealing with a Fredo in the firm is stressful and unpleasant, allowing one to remain unchecked can eventually cause irreparable damage to the business and the family. Some families have even sold their businesses rather than try to stop their Fredo. As the above advice suggests, discourage Fredos from entering the family business in the first place by creating and implementing rules of entry. Family businesses would also be wise to establish human resources practices that hold family members accountable for their behaviors. Most important, family businesses need to realize that doing nothing usually makes the problem worse. Those suffering at the hands of a Fredo also need to realize that they are not alone.

\section{References}

Eddleston, K.A. \& Kidwell, R.E. 2012. Parent-child relationships: Planting the seeds of deviant behavior in the family firm. Entrepreneurship Theory \& Practice, 36 (2): 369-386.

Kidwell, R. E., Eddleston, K. A., Cater, J. J., \& Kellermanns, F. W. (2013). How one bad family member can undermine a family firm: Preventing the Fredo effect. Business Horizons, 56(1), 5-12.

Kidwell, R.E., Kellermanns, F.W. \& Eddleston, K.A. 2012. Harmony, justice, confusion and conflict in family firms: Implications for ethical climate and the "Fredo effect." Journal of Business Ethics, 106 (4): 503-517. 